\title{
Bringing the dead compartment of a plant cell to life: a novel imaging technique resurrects the dynamic nature of the apoplast
}

\author{
Doug Van Hoewyk* \\ Department of Biology, Coastal Carolina University, Conway, SC, USA \\ *Correspondence: dougvh@coastal.edu
}

\section{A commentary on}

Real-time imaging of leaf apoplastic $\mathrm{pH}$ dynamics in response to $\mathrm{NaCl}$ stress by Geilfus, C. M., and Mühling, K. H. (2011). Real-time imaging of leaf apoplastic $\mathrm{pH}$ dynamics in response to $\mathrm{NaCl}$ stress. Front. Plant Sci. 2:13. doi: 10.3389/fpls.2011.00013

In vivo imaging has made significant contributions to plant biology over the past decade. Notable advances in bioimaging have enabled a more comprehensive understanding of many plant-related topics, including photosynthetic electron transport (Ehlert and Hincha, 2008), viral pathogenesis (Tilsner and Oparka, 2010), and the role of reactive oxygen species (Swanson et al., 2011). Now it appears that the benefits of in planta imaging have been extended to the realms of the non-living. Geilfus and Mühling (2011) report in Frontiers in Plant Nutrition a novel non-invasive technique that allows for the direct quantification of ion and $\mathrm{pH}$ dynamics in the apoplast. Perhaps most noteworthy, the authors demonstrate the ability to quantify $\mathrm{pH}$ fluctuation in different apoplastic compartments in the leaves less than $3 \mathrm{~h}$ after roots are subjected to salt stress.

The newly developed method reliably measures apoplastic $\mathrm{pH}$ both temporally and spatially in a living plant. Briefly, the technique uses a diffusible and fluorescent dye (Oregon Green 488) that is loaded into the apoplast of intact leaves in the common bean (Vicia faba). The $\mathrm{pH}$ sensitive, photostable dye is conjugated to a dextran molecule that prevents its movement into the symplast. Fluorescence microscopy is used to estimate apoplastic $\mathrm{pH}$ using the fluorescence ratio of F495/F444. Such ratio imaging is possible, because while the fluorescence of the dye at $\mathrm{F} 495$ is $\mathrm{pH}$ dependent, the concentration of Oregon Green is corrected by the fluorescence at F444, which is not sensitive to $\mathrm{H}^{+}$concentration.
Therefore, the in situ fluorescence ratio of the two wavelengths only provides a direct estimation of apoplastic $\mathrm{pH}$, and is not affected by the dye concentration.

The functions of the apoplast in plant physiology and development varies enormously (Sattelmacher, 2001). Similarly, the potential application of this new method could extend far beyond the studies pertaining to crop stress physiology; the newly described technique to measure apoplastic $\mathrm{pH}$ both temporally and spatially could be transformative to a variety of disciplines in plant biology. First, the new approach to study changes in apoplastic $\mathrm{pH}$ could improve plant nutrient acquisition. For example, although the apoplast provides a continuum for the bulk flow of water and essential plant nutrients, membrane-bound proton pumps can greatly affect the acidity in localized regions of the apoplast. $\mathrm{H}^{+}$ ATPases can therefore create a polarized microenvironment in the apoplast that can (i) drive cations down their electrochemical gradient into the symplast or (ii) facilitate the movement of anions across the cell membrane via co-transporters. Therefore, a better conceptual framework of apoplastic $\mathrm{pH}$ dynamics may potentially allow the screening and development of new crop varieties with enhanced nutritional content. Secondly, because accumulation of cations is dependent upon apoplastic $\mathrm{pH}$, advances in the phytoremediation of soils or groundwater containing excessive amounts of $\mathrm{Al}, \mathrm{Cu}, \mathrm{Fe}$, and $\mathrm{Zn}$ may also be possible due to knowledge gleaned by utilizing the new technique developed by Geilfus and Mühling (2011). Lastly, a decrease in apoplastic $\mathrm{pH}$ is associated with cell-wall relaxation and cell elongation. In view of the acid growth theory, enhancing our understanding of apoplastic $\mathrm{pH}$ dynamics is relevant to plant growth and biomass. In this context, knowledge of apoplastic $\mathrm{pH}$ fluctuations could be far-reaching and applied to research in agriculture or cellulosic ethanol.
A reliable method to measure apoplastic $\mathrm{pH}$ in intact leaves has long been awaited. A review and assessment of techniques to quantify apoplastic $\mathrm{pH}$ notes the limitations of previously employed methods (Yu et al., 2000). The new technique by Geilfus and Mühling (2011) overcomes difficulties encountered with previous methods to estimate apoplastic $\mathrm{pH}$, and comes with the added bonus that $\mathrm{pH}$ can be discriminated both spatially and temporally. The new protocol presented by Geilfus and Mühling (2011) ushers in the coming of age for the in planta imaging of apoplastic $\mathrm{pH}$ dynamics, and perhaps with it a better understanding of the extracellular space in plants.

\section{REFERENCES}

Ehlert, B., and Hincha, D. K. (2008). Chlorophyll fluorescence imaging accurately quantifies freezing damage and cold acclimation responses in Arabidopsis leaves. Plant Methods 4, 12.

Geilfus, C. M., and Mühling, K. H. (2011). Real-time imaging of leaf apoplastic $\mathrm{pH}$ dynamics in response to $\mathrm{NaCl}$ stress. Front. Plant Sci. 2:13. doi: 10.3389/ fpls.2011.00013

Sattelmacher, B. (2001). The apoplast and its significance for plant mineral nutrition. New Phytol. 49, 167-192.

Swanson, S. J., Choi, W. J., Chanoca, A., and Gilroy, S. (2011). In vivo imaging of $\mathrm{Ca}^{+}, \mathrm{pH}$, and reactive oxygen species using fluorescent probes in plants. Ann. Rev. Plant Biol. 62, 273-297.

Tilsner, J., and Oparka, K. J. (2010). Tracking the green invaders: advances in imaging virus infection in plants. Biochem. J. 430, 21-37.

Yu, Q., Tang, C., and Kuo, J. (2000). A critical review on methods to measure apoplastic $\mathrm{pH}$ in plants. Plants Soil 219, 29-40.

Received: 29 August 2011; accepted: 30 August 2011; published online: 21 September 2011.

Citation: Van Hoewyk D (2011) Bringing the dead compartment of a plant cell to life: a novel imaging technique resurrects the dynamic nature of the apoplast. Front. Plant Sci. 2:52. doi: 10.3389/fpls.2011.00052

This article was submitted to Frontiers in Plant Nutrition, a specialty of Frontiers in Plant Science.

Copyright $\odot 2011$ Van Hoewyk. This is an open-access article subject to a non-exclusive license between the authors and Frontiers Media SA, which permits use, distribution and reproduction in other forums, provided the original authors and source are credited and other Frontiers conditions are complied with. 